\title{
Social security as a field of Euroregional cooperation. Deliberations on the example of the activity of the Euroregion "Beskidy"
}

\author{
Sabina Sanetra-Półgrabi ${ }^{1}$ A; Aleksander Sapiński ${ }^{2}$ B \\ A Pedagogicla University of Cracov, ul. Podchorążych 2, Kraków, Poland

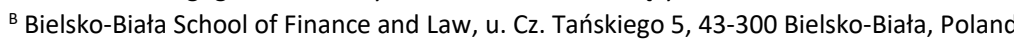

Received: March 1, 2021 | Revised: April 11, 2021 | Accepted: April 30, 2021

DOI: $10.33445 /$ sds.2021.11.2.2

\begin{abstract}
The main aim of this article is to present the concept of the Euroregion as a platform for cooperation in the area of social security. The issue itself needs to be constantly updated not only because of the constant challenges facing the European Union and other countries. The outlook character of the article presents a view on the importance of cooperation between selfgovernment administration bodies and other subjects of economic life for the development of cooperation within the Euroregions. The article mainly focuses on the fight against often negative stereotypes and undertakings whose task is to increase the standard of economic life by increasing activities aimed at improving the quality of Euroregional cooperation. The Euroregion "Beskidy" was selected for the study, which is diverse in ethnic, sociological, historical, but also economic and social terms. Its unique features have allowed the authors to more clearly emphasize the message of the article. Tourism and its international, Euro-regional character is also an important element of cooperation. In order to carry out the research that resulted in this article, the methods of researching the sources sucked in in terms of critical analysis of literature were used, as well as juxtaposing them with the previously conducted research on Euroregions and safety by the authors. On the basis of the analysis, the article presents a significant contribution of social integration and cross-border cooperation to the development of the Euroregion as well as to the development of social security as a non-military part of the research topic. The creation of new types of innovative pro-social undertakings opens up the Euroregions, and thus the Member States to further internal integration and intensification of activities to strengthen socio-economic cooperation with neighboring countries.
\end{abstract}

Key words: social security, security, euroregion, cross-border cooperation, tourism.

\section{Introduction}

Security generally appears as a concept, an academic discipline and an object of activity for policy-makers. In the latter view, internal security, organised in a state in the form of legal regulations and a system of supervisory bodies and services, inspections and guards subordinate to them, is the most crucial.

In the security sciences we deal with the security of the state, often identified with national security and its non-military aspects, among which social security is analysed together with the following dimensions: cultural, ecological, informational and economic. Sometimes the financial, energy and food dimensions are also singled out as categories of security analysis. In any case, all the proposed sectors are very necessary and appear in numerous analyses in security sciences (Wojciechowski, S.).

Turning to social security, it is first worth

${ }^{1}$ Corresponding author: Adiunkt, Instytut Prawa, Administracji i Ekonomii, e-mail: sabina.sanetra-polgrabi@up.krakow.pl

2 Ph.D student, MSc, Lecturer of Bielsko-Biała School of Finance and Law, e-mail: asapinski@wsfip.edu.pl 
noting that it is probably the most local and individual in nature. On the one hand it is related to the system of global collective security, led by legal regulations and the influence of universal and specialized organizations, such as the United Nations, the International Labour Organization, the Organization for Security and Co-operation in Europe or the Council of Europe and the European Union. On the other hand, many studies provide definitions of social safety in close connection with the social policy pursued at national, regional and local levels and it is generally difficult to separate the two issues without careful analysis. Therefore, in this text, the authors first of all characterise social safety as a field and objective of cooperation between local government units located in the immediate vicinity of the state border, which is referred to as cross-border, crossborder or euroregional. In the further part of the text, the authors will use the last of the distinguished notions, and it results from the concentration on the analysis of the hitherto activity of one selected Euroregion, which is the Euroregion "Beskidy". On the basis of the collected materials, including the literature on the subject, development strategies and other generally available studies, the meaning of social security, the way it is perceived and the directions it is provided within the activity of the Polish-Czech-Slovak Euroregion "Beskidy" will be shown. According to the authors, the twenty years of functioning of the cross-border structure and the objectives of the cooperation included in the quoted development strategies testify that many undertakings fall within the framework of social security. These include in particular: initiatives aimed at combating negative stereotypes, undertakings aimed at raising the economic level and integration around common values as well as intensifying cooperation in solving cross-border problems. It is on these aspects that the authors of this article wish to focus.

\section{Results and discussion}

\section{Social security - understanding, dimensions, threats}

Many studies have been written on the nonmilitary aspects of security. We may risk a statement that nowadays they constitute a dynamic area of research exploration. As far as the discussed issue is concerned, it is worth noting at the outset that it is related to the national security system of the state, which is aimed at social development, welfare, social minimum and survival not only of the state as a whole, but also of the social groups living within its borders. In this aspect it is noticeable that social security is defined as a special type, field, research area in security sciences. This is very well reflected in the approach of R. Jakubczak, $R$. Kalinowski and K. Loranty. According to Jakubczak, Kalinowski and Loranty, "social safety is such a quality of the society's culture, social structure and system of work division, which enables the citizens to achieve individual values and manifests itself in the undertaking of cooperative actions by individuals, natural and formal groups, oriented towards the common good and the realisation of recognised cultural values with the use of accepted means, as well as the maintenance and strengthening of social bonds, ensuring the formation of the community identity of the community covered by the political organisation of the state" (Jakubczak, R.).

Another way of defining social security is to link it to social policy, which is realised by state and local administration. In this context, the most adequate definition is that proposed by $\mathrm{M}$. Leszczyński, according to whom social safety includes "the whole range of legal and organisational activities carried out by governmental (national and international), nongovernmental entities and citizens themselves, which are aimed at ensuring a certain standard of living for individuals, families and social groups, and preventing their marginalisation and social exclusion. In particular, it is about providing assistance to people who are temporarily or permanently unable to work, who 
have found themselves in a difficult life situation as a result of their own incompetence, or who have fallen victim to random events beyond their control, such as fire, flood or other natural disasters" (Leszczyński, M.).

We may risk a statement that the above definitions emphasise the social dimension of social security, but there are also references to the community and development aspect. It is these three dimensions of analysis that dominate many studies on social security. The first one includes the livelihood objective, i.e., the guarantee of minimum social standards through an organised system of transfers and incomes, the next one is closely related to the area of social capital, and the last one - the developmental dimension of social safety analysis is contained in the provision by the state of adequate educational conditions, the implementation of professional paths, or the creation of institutional conditions for the empowerment of citizens in the legal system (Leszczyński, M.).

The characterised dimensions of social safety and their diversity mean that the analysis of social safety threats should be undertaken in the same general way. Thus, according to B. Hołysta, apart from the typical dangers associated with functioning in a social group, the sense of integrity of an individual is also affected by the forces of nature, including space and all environmental pollution, as well as civilization and consumer threats, which are the repercussions of economic and socio-political transformations. Certainly, social threats include the effects of globalisation, cyber threats and the uncontrolled growth of large cities (Hołyst, B.). An equally capacious classification of threats to social security is presented by J. Supińska, where among natural disasters and negative aspects of technological progress and armed conflicts, the author sees the dangerous influence of other social groups and self-destruction of the individual himself (Supińska, J.).

Certainly, threats to social security, as well as its very definition, is an extremely complex issue and requires detailed justification in each case. For the authors of the text, the developmental dimension of studying and defining social security is very important. In particular, the role of the local authorities' cooperation to increase the development opportunities of the given local government unit, as well as its closest surroundings, and initiatives that are part of the fight against emerging constraints. One example of bottom-up activities is cross-border cooperation, either in a formalised way or as support for such projects.

\section{General comments on Euroregional} cooperation

The main aim of cross-border cooperation since the beginning of the 1990s was the integration of local communities. At the same time, the first effects of the established Euroregional structures showed that it is very difficult to successfully implement cross-border projects. This was influenced by the numerous political, legal and economic transformations that emerged in Poland and Central and Eastern Europe. Certainly, the institutional and economic reforms carried out in Poland at the turn of the 1980s and 1990s and then in the second half of the 1990s brought about many changes which were also beneficial for the gradually emerging euroregions, including the possibility of benefiting from pre-accession assistance.

Currently, since Poland's accession to the European Union, we have participated in two programming periods, new possibilities to implement cross-border initiatives and legal and institutional forms of activity have emerged. In general, there are several types of realization of external cooperation of territorial selfgovernments, to which the most general can be classified: Euroregions, agreements in the form of twin towns, cross-border clusters, European Groupings of Cross-border Cooperation or other networks, more or less formalised structures (Szczechowicz, H.).

These forms of cross-border activity have much in common and much in common at the same time. Certainly, their structure and activities were influenced by numerous legal, economic and international conditions. The issue of the implemented model of cooperation is also important. A closer look at the structure 
of the currently functioning sixteen Euroregions reveals that the bottom-up, self-governing model of cooperation generally prevails. In Poland, with the participation of the government, cross-border structures have been created in the eastern and partly in the northern borderlands (these are the Carpathian, Bug and Baltic Euroregions) (Szczechowicz, H.).

In terms of its conception, the Euroregion can be defined in various ways, but in most cases, it is an area spatially connected to a specific geographical area and includes border parts of two or more countries that wish to cooperate and coordinate local communities in various activities. Euroregion is distinguished by the following features: a high degree of institutionalisation, i.e. it is most often a formal structure, a platform for cross-border cooperation, bringing together representatives of local and regional authorities and sometimes economic and social partners. The advanced level of integration within the Euroregion means that, over time, a cross-border region can be defined as a specific type of Euroregion: a territory on both sides of a national border, constituting a homogeneous complex of territories with common features, whose population has common cultural traditions and wishes to cooperate in order to stimulate cultural, social and economic progress. An example is the Euroregion Sar - Lor - Lux located on the French-Belgian-Luxembourg border (Studzieniecki, T.).

\section{Euroregion "Beskidy" - general characteristics}

The analyzed Euroregion "Beskidy" is located on the southern border of Poland. It is the only cross-border structure so far, in which participate territorial units from Czech Republic, Slovakia and Poland, formally established in Rajcza on June 9, 2000. The overall objective of the cooperation was the development of tourism, activities to cultivate common values and traditions related to the Beskydy region and economic cooperation. Other, equally important goals of Euroregion's activity were: environmental protection, undertakings complying with the rule of sustainable development, intensified cooperation of institutions, including local authorities, small and medium enterprises, schools and universities and associations (Przybyła, Z.).

As far as the parties to the cooperation are concerned, there are three local government associations consisting of local government units and economic entities, non-governmental organizations and private persons, meritorious for the border area (Przybyła, Z.).

In total, the Beskidy Euroregion covers an area of about $6343 \mathrm{~km}^{2}$, including the Polish part: $3288 \mathrm{~km}^{2}$, Slovak: $2083 \mathrm{~km}^{2}$, Czech: 972 $\mathrm{km}^{2}$. The area is inhabited by almost 1385036 people (Poles - 843 536; Slovaks - 295 500, Czechs - 246 000) (Sanetra-Półgrabi, S.).

Analysing the achievements to date, to a large extent they have been connected with the set goals, which have already been indicated and specified in the Strategy of the Euroregion "Beskidy", whose assumptions were adopted on 25 August 2000. Further activity of local authorities creating the Euroregion shows that many initiatives have been successfully realized or initiated. In the strategic document four main goals were indicated: to develop the processes integrating the Euroregion community and shaping the local democracy, to develop economically, to ensure the care about the richness of nature resources and environment protection and to optimally develop the human capital and to raise the quality of life of PolishCzech-Slovak border area inhabitants. In a similar way, it defines the tasks for local authorities and other members gathered in the Euroregion "Beskidy" another strategic document, i.e. the Development Strategy of the Euroregion "Beskidy" for 2016-2023, focusing on: promotion of tourism in the context of employment growth, livelihood, development of natural and cultural resources and cooperation of institutions and communities in the field of education, nature and landscape protection, preparation of cross-border infrastructure projects, and in the field of recreation, provision of public services, including creation of cooperation networks and increasing the level of information about the common area (Obszar i liczba).

The first years of the Euroregion operation 
(2000-2005) showed that first of all it was necessary to build an institutional basis for cooperation, adjust to the current international situation including meeting the requirements of Poland's accession to the European Union and undertake promotional activities. As shown by many initiatives, the main axis of cooperation was and is tourism. It is around tourism that marketing, economic, educational and social projects were carried out. Thanks to the development of this field of cooperation it was possible to support local technical, economic, social and municipal infrastructure, improve inter-organizational relations and support local cultural heritage, and undertake initiatives for sustainable development (Strategia Rozwoju Euroregionu).

Through the development of cross-border tourism cooperation it has also been possible to influence social development and to some extent also economic potential, as shown by the consecutive years of activity of the Euroregion "Beskidy" (2005-2015). Examples of successful initiatives in this regard include: the "Entrepreneurship without borders" project, the training "Legal aspects of safe trade cooperation on the Slovak market", and the Euroregion "Beskydy" Local Government Tournament. In the current programming period (2014-2020), the Polish side of the Euroregion "Beskidy" - the Association "Region Beskidy" is implementing two projects as part of the Crossborder Cooperation Programme Interreg VA Poland - Slovakia 2014-2020: "Protection and development of natural and cultural heritage of the border area" and "Development of crossborder education and lifelong learning" (Sanetra-Półgrabi, S.; Projekty własne Euroregionu).

Social security as an area of Euroregional cooperation on the example of the Euroregion "Beskidy"

Before discussing the role of the analyzed Euroregion "Beskidy" in the field of shaping social security in the borderlands, it should be noted that very few studies have been written in this area. Most publications are devoted to the cooperation of the Police, Border Guards and other formations, including services, inspections and guards to build internal security, including the fight against major threats to the functioning of key institutions in the Member State (Gruszczak, A.; Ilnicki, M.; Szachoń-Pszenny, A.).

A. Pokrzywka-Szkarska writes about the need to conduct strictly social research. PokrzywkaSzkarska noting: "The practice of Euroregional activities, implemented projects of a crossborder nature, which require the cooperation of partners from both (or more) sides of the border, as well as the postulates of local political and intellectual elites convince that processes of creating a cross-border community are both desirable and possible. (...) However, the kitsch of cross-borderism, i.e. the rapid intensification and glorification of cross-border cooperation projects, can only be a consequence of wishful thinking on the part of the elites. Meanwhile, the real knitting together of communities has to take place at all levels, not only at the level of the elites, in everyday life there would have to be permanent contacts and exchanges, flows of values, and not only on the occasion of Euroregional and territorial cooperation projects". Thus, as the Author further states: "the defence against the kitsch of crossborderism is to study the real manifestations of cross-border cooperation, to study the community, its awareness and manifestations of ties and social contacts across national borders. The existence of a cross-border community is certainly desirable from many points of view, but one has to be careful. In order not to prematurely announce the success of this great European integration project" (Pokrzywska A.).

Analysing the role of the Euroregion "Beskidy" more broadly, it should be pointed out that practically in each of the realized projects the influence on the level of social security could be seen, especially this role refers to the developmental dimension, although social and community aspects are also present. Above all, successful tourism projects have improved the local labour market, upgraded municipal infrastructure linked to the tourism and recreation sectors and promoted the Beskydy area at international tourism fairs. The activity of the Silesian Tourism Organisation, the Beskid Association of Cyclists or the Association 
"Pracownia na rzecz Wszystkich Istot" was very important in these fields. [20].

Tourism, having a strictly integrative character, influenced good neighbourly relations and education. Within the framework of the "Beskidy" Euroregion numerous conferences and seminars were held on the Polish side which in many cases resulted in cross-border publications. Thanks to educational initiatives, it was possible to tighten scientific cooperation and there was an exchange of good practices and specialist needs. Scientific and educational cooperation can be exemplified by the conferences "Business Activator". From passion to idea and business activity in tourism, the conference " 10 years of the Euroregion "Beskidy" or seminars and trainings (Sanetra-Półgrabi, S.).

Local authorities in the area of the Euroregion "Beskidy" devote relatively much attention to the process of social exclusion, trying to fight it in all possible ways, including participating as initiators of cultural initiatives, including exhibitions, competitions, folklore meetings, etc. (Sanetra-Półgrabi, S.).

\section{Conclusions}

Social security as a non-military segment of security has a very local, community, social and developmental character. It is related to the totality of institutional, legal, social and economic undertakings undertaken by the state, local authorities and non-governmental organisations. It is linked to social policy and other "soft" areas of security.

This paper points to one of the institutional and legal manifestations of the influence on social security which is the cross-border cooperation established in the form of Euroregions. This is particularly evidenced by the following activities of the Euroregions: orientation towards the local community, social integration, educational and cultural initiatives, which are intended to bring together, exchange experiences, acquire valuable skills, knowledge of the legal system, institutions, and ways of conducting business in border areas. Another important element within the Euroregions is the participation in cross-border projects aimed at counteracting spatial, communicational and social marginalisation and the implementation or co-implementation of preventive programmes or projects aimed at safety and crisis management.

On the example of the analyzed Euroregion "Beskidy" the main initiatives with potential impact on social security are presented. The presented activities are directly or indirectly connected with tourism, so we can risk a statement that in border areas with both natural and cultural values it is possible to build social safety oriented on local community, its professional, community and development potential. In case of Euroregion "Beskidy" tourism is an important goal of activity and content of other undertakings. All of them are intended by local authorities and other Euroregion members to bring people closer together, to develop social and economic development, and to launch other forms of cross-border partnership cooperation.

\section{References}

Wojciechowski, S., Skrażyński, M., Magiera, M. Teoretyczne i praktyczne aspekty bezpieczeństwa Polski, [ w:] A. Wejkszner, S. Wojceichowski, Współczesne bezpieczeństwo Polski. Międzynarodowy wymiar instytucjonalny, Warszawa 2019, s. 21-25, Jakubczak, R., Kalinowski, R., Loranty, K. Bezpieczeństwo społeczne $w$ erze globalizacji, Siedlce 2008, s. 57-61,
Leszczyński, M. Bezpieczeństwo społeczne a bezpieczeństwo państwa, Kielce 2009 s. 37, Leszczyński, M. Wybrane aspekty bezpieczeństwa społecznego, Ostrowiec Świętokrzyski - Kielce 2011, s. 58,

Hołyst, B. Zagrożenia ładu społecznego, T. I, Warszawa 2013, s. 27-35,

Supińska, J. Dylematy polityki społecznej, Warszawa 1991, s. 56, 
Szczechowicz, H. Istota i znaczenie Sanetra-Półgrabi, S. Funkcjonowanie międzynarodowej współpracy jednostek euroregionów na pograniczu południowym samorządu terytorialnego, "Zeszyty Polski. Studium porównawcze trzech Naukowe Państwowej Wyższej Szkoły Euroregionów: "Ślqqsk Cieszyński", "Beskidy" $i$ Zawodowej we Włocławku", 2013, t. IX, s. 266.

Studzieniecki, T. Strategie rozwoju polskich euroregionów, „Przedsiębiorczość i Zarządzanie", 2015, T. XVI, s. 14-15.

Przybyła, Z. Perspektywy euroregionalizacji polskiego pogranicza w świetle doświadczeń, "Przegląd Zachodniopomorski", 2014, T. 29, s. 14-19.

Sanetra-Półgrabi, S. Funkcjonowanie euroregionów na pograniczu południowym Polski. Studium porównawcze trzech Euroregionów: "Ślqqsk Cieszyński", "Beskidy" $i$ "Tatry", Toruń 2015.

Obszar i liczba mieszkańców Euroregionu "Beskidy", Available from: http://www.euroregionbeskidy.pl/euroregion-beskidy-2/oeuroregionie/ [data dostępu: 14.02.2020]

Strategia Rozwoju Euroregionu "Beskidy" na lata 2016-2023, Available from: http://www.euroregionbeskidy.pl/mikroprojekty/interreg-plcz/strategia-rozwoju-euroregionu-beskidy2016-2023/ [data dostępu: 15.02.2020] "Tatry", Toruń 2015.

Projekty własne Euroregionu "Beskidy", Available from: http://www.euroregionbeskidy.pl/projekty-wlasne/ [data dostępu: 15.02.2020]

Gruszczak, A. Współpraca policyjna w Unii Europejskiej w wymiarze trans granicznym. Aspekty polityczne i prawne, Kraków 2009, Ilnicki, M. Stużby graniczne $w$ walce $z$ terroryzmem. Polskie warunki ustrojowoprawne, Toruń 2011,

Szachoń-Pszenny, A. Acquis Schengen a granice wewnętrzne i zewnętrzne w Unii Europejskiej, Poznań 2011,

Pokrzywska A. - Szklarska, Od granicy do transgranicza. Rozważania teoretyczne na marginesie problematyki euroregionów, [w:] Z. W. Puślecki (red.), Unia Europejska w procesie zmian na poczqtku XXI wieku, Toruń 2014, s. 117-118.

Sanetra-Półgrabi, S. Funkcjonowanie euroregionów na pograniczu południowym Polski. Studium porównawcze trzech Euroregionów: "Ślqqsk Cieszyński", "Beskidy" $i$ "Tatry", Toruń 2015. 